\title{
GAMBARAN HISTOPATOLOGIK TESTIS TIKUS WISTAR (Rattus norvegicus) SETELAH PEMBERIAN MONOSODIUM GLUTAMATE (MSG)
}

\author{
${ }^{1}$ Ririen Sylvia Sagita Bilondatu \\ ${ }^{2}$ Meilany Durry \\ 2 Poppy Lintong
}

\author{
${ }^{1}$ Kandidat Skripsi Fakultas Kedokteran Universitas Sam Ratulangi \\ ${ }^{2}$ Bagian Patologi Anatomi Fakultas Kedokteran Universitas Sam Ratulangi \\ Email: ririenssbilondatu@gmail.com
}

\begin{abstract}
Monosodium glutamate (MSG) is a sodium salt from glutamic acid which is currently very popular to be used as a food flavoring ingredient to stimulate appetite. The objective of the study to discover the histologic findings of wistar rats' testicles after MSG administration. This was an experimental laboratoric study, using 20 wistar rats that has been divided into 4 groups. The negative control group is given standard pallet and drinking water for 40 days; it devided to 2 smaller groups, K1 and K2, each of the group was terminated on the $21^{\text {st }}$ and $41^{\text {st }}$ day. The intervention group was given MSG according to average consumption dose in Indonesia; it devided to two smaller groups, P1 and P2, each group was terminated on the $21^{\text {st }}$ and $41^{\text {st }}$ day. The result showed on group $\mathrm{K} 1$ and $\mathrm{K} 2$, a normal finding of seminiferous tubules, spermatogenic cell layer arrays, and interstitial cell density was found. On group P1, showed seminiferous tubules with decrease of spermatogenic cells development, causing the tubules compartment to appear vacant; the spermatogonia layers appeared sparse on basal membrane, and fewer interstitial cells. On group $\mathrm{P} 2$, the findings were not of much difference with group P1, but in this group, one testicle specimen showed calcification cells inside its seminiferous tubules was found. Conclusion: Administration of MSG according to average consumption dose in Indonesia causes decrease of seminiferous tubules' diameter and decrease of the number of spermatogenic cells and interstitial cells.
\end{abstract}

Keywords: Monosodium glutamate (MSG), Indonesia average consumption dose, testicles.

Abstrak: Monosodium glutamate (MSG) adalah garam natrium dari asam glutamat yang saat ini
sangat popular digunakan sebagai bahan penyedap makanan untuk merangsang selera. Penelitian
ini bertujuan untuk mengetahui gambaran histologik testis tikus wistar setelah pemberian MSG.
Jenis penelitian ini ialah eksperimental laboratorik, menggunakan 20 ekor tikus wistar yang dibagi
menjadi 4 kelompok. Kelompok kontrol negatif terdiri dari dua kelompok yakni K1 dan K2,
masing-masing diterminasi pada hari ke-21 dan hari ke-41. Kelompok perlakuan diberi MSG
sesuai dosis konsumsi rata-rata di Indonesia, terdiri dari dua kelompok yakni P1 dan P2, masing-
masing diterminasi pada hari ke-21 dan hari ke- 41 . Hasil penelitian menunjukkan pada kelompok
K1 dan K2 didapatkan gambaran tubulus semineferus, susunan lapisan sel spermatogenik dan
kepadatan sel interstisial yang normal. Pada kelompok P1 didapatkan gambaran fokus-fokus
tubulus semineferus tanpa perkembangan sel-sel spermatogenik sehingga ruang tubulus tampak
kosong, lapisan spermatogonia yang saling jarang pada membran basalis, dan sedikit sel
interstisial. Pada kelompok P2 didapatkan gambaran yang tak jauh berbeda dengan kelompok P1, 
namun pada kelompok ini didapatkan satu sediaan testis yang tampak ruang tubulus semineferusnya berisi sel-sel yang mengalami kalsifikasi. Simpulan: Pemberian MSG sesuai dosis konsumsi rata-rata di Indonesia menyebabkan mengecilnya diameter tubulus semineferus, penurunan jumlah lapisan sel-sel spermatogenik dan berkurangnya sel interstisial.

Kata Kunci: Monosodium glutamate (MSG), dosis rata-rata konsumsi Indonesia, testis.

Monosodium glutamate atau dikenal dengan MSG adalah garam natrium dari asam glutamat yang saat ini sangat popular digunakan sebagai bahan penyedap makanan untuk merangsang selera. ${ }^{1}$ Monosodium glutamate dapat ditemukan pada berbagai makanan kemasan atau kaleng meskipun seringkali produsen tidak mencantumkan MSG pada label secara jelas. ${ }^{2-4}$

Komposisi senyawa MSG adalah $78 \%$ asam glutamat, $12 \%$ natrium dan $10 \%$ air. Asam glutamat merupakan asam amino penyusun protein dan merupakan komponen alami dalam setiap makhluk hidup baik dalam bentuk terikat maupun bebas. ${ }^{5}$ Glutamat yang masih terikat dengan asam amino lain sebagai protein tidak memiliki rasa, tetapi dalam bentuk bebas memiliki rasa gurih, sehingga semakin tinggi kandungan glutamat bebas dalam suatu makanan maka semakin kuat rasa gurihnya. Namun glutamat bebas dalam makanan sehari-hari (seperti daging, ikan, susu dan sayuran) umumnya rendah, sehingga untuk memperkuat cita rasa perlu adanya tambahan bumbu yang kaya kandungan glutamat bebas. Glutamat bebas tersebut bereaksi dengan ion natrium membentuk garam MSG.,

Penggunaan dan keamanan MSG sampai saat ini masih menjadi perdebatan. Food and Drugs Administration (1995) menyatakan bahwa MSG adalah bahan makanan yang aman bagi manusia apabila dikonsumsi dalam dosis lazim. ${ }^{8,9}$ Namun demikian, berbagai penelitian melaporkan adanya efek yang timbul setelah mengkonsumsi MSG, satu diantaranya adalah MSG Symptom Complex yang ditandai dengan rasa panas di wajah, leher, lengan dan dada, sakit kepala, mual, berdebar-debar dan kadang sampai muntah. Laporan lainnya menunjukan bahwa MSG memberi efek toksik bagi manusia dan hewan percobaan pada berbagai sistem organ, termasuk organ reproduksi. ${ }^{10,11}$ Middle East Fertility Society Journal (2014) melaporkan bahwa pemberian MSG dengan dosis 30 dan $60 \mathrm{~g} / \mathrm{kgBB}$ secara injeksi intraperitoneal ke tikus wistar jantan menyebabkan atrofi tubulus semineferus akibat nekrosis sel-sel spermatogenik. ${ }^{3}$

Menurut WHO produksi MSG mencapai 200.000 ton per tahunnya dan penggunaannya sekitar 3 gram sehari di Negara-negara Asia. ${ }^{9}$ Geha et al (2001) memiliki pandangan berbeda dalam memperkirakan jumlah konsumsi MSG, diperkirakan rata-rata asupan harian MSG 0,3-1,0 g di negara-negara industri, tetapi bisa lebih tinggi tergantung jenis makanan yang mempunyai kandungan glutamat bebas sebelumnya, serta pilihan rasa masingmasing individu. ${ }^{11}$ Menurut studi Prawirohardjono (2000) dosis rata-rata konsumsi di Indonesia adalah $0.6 \mathrm{~g} / \mathrm{hari}^{12}$ Penggunaan MSG di Indonesia per hari masih terhitung sangat rendah dibandingkan di Negara industri maupun di Negara maju. Namun, akumulasi terus menerus dalam dosis rendah juga perlu diwaspadai. ${ }^{10}$ Oleh karena itu dibutuhkan penelitian lebih lanjut mengenai efek yang ditimbulkan dalam pemakaian MSG meskipun dalam konsentrasi yang rendah.

Berdasarkan uraian diatas, penulis tertarik untuk melakukan penelitian mengenai pengaruh MSG terhadap testis tikus wistar sesuai dosis konsumsi rata-rata di Indonesia.

\section{METODE PENELITIAN}

Penelitian ini merupakan penelitian eksperimen laboratorik. Penelitian dilakukan di Laboratorium Patologi Anatomi Fakultas Kedokteran Universitas Sam Ratulangi Manado periode Agustus - Desember 2016. Subjek penelitian yang digunakan adalah 20 
ekor tikus jantan galur wistar dewasa dalam keadaan sehat, memiliki berat 200-250 gram.

Monosodium glutamate (MSG) yang digunakan diperoleh dari pasaran bebas dengan merek dagang Ajinomoto produksi PT. Ajinomoto Indonesia, bubuk MSG berupa kristal putih mengandung monosodium glutamate murni dan terbungkus rapi dalam kantong plastik tertutup dan menggunakan dosis rata-rata konsumsi di Indonesia. ${ }^{12}$ Dosis lalu dikonversikan sesuai berat badan tikus yakni 200 gram, sehingga diperoleh dosis 12.4 $\mathrm{mg} / \mathrm{gBB}$ tikus. Dosis yang sudah ditetapkan dilarutkan dalam $1 \mathrm{ml}$ aquades kemudian diberikan secara oral menggunakan sonde lambung sehari sekali.

Kelompok kontrol negatif terdiri dari 2 kelompok yakni K1dan K2 yang diberi makan pelet dan air minum selama 40 hari kemudian masing-masing kelompok diterminasi hari ke-21 dan hari ke-41. Kelompok perlakuan I (P1) diberi pelet, air minum dan MSG sesuai dosis yang ditetapkan selama 20 hari, diterminasi hari ke-21. Kelompok perlakuan II diberi pelet, air minum dan MSG sesuai dosis yang ditetapkan selama 40 hari, diterminasi hari ke-41.

Gambaran histologik testis yang akan dinilai meliputi diameter tubulus semineferus, jumlah lapisan sel spermatogenik dan kepadatan sel interstisial secara kualitatif.

\section{HASIL PENELITIAN \\ Gambaran Histopatologik \\ Kelompok kontrol negatif I (K1)}

Tikus wistar kelompok ini merupakan kontrol negatif selama 20 hari. Pada semua sediaan testis kelompok ini tampak tubulus semineferus dengan susunan lapisan sel spermatogenik yang normal dan sesuai dengan tingkat perkembangannya dari membran basalis ke arah lumen tubulus yakni spermatogonia, spermatosit, spermatid hingga spermatozoon (Gambar 1).

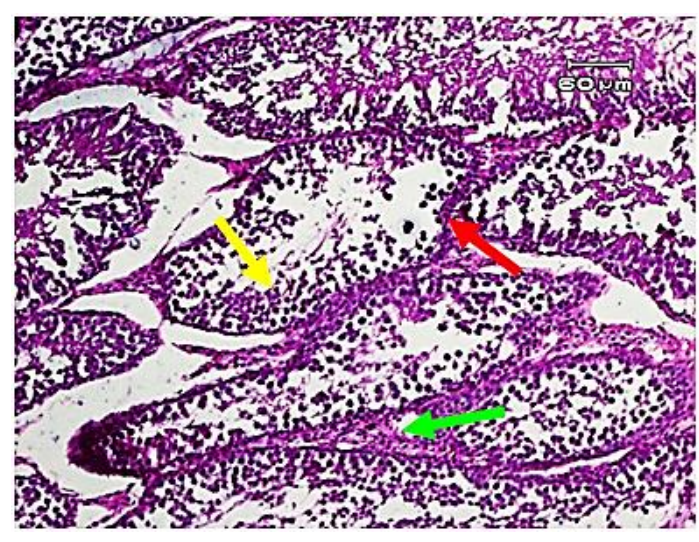

Gambar 1. Gambaran mikroskopik testis wistar Kelompok kontrol negatif 20 hari (K1). Tampak tubulus semineferus (panah merah), susunan lapisan sel spermatogenik (panah kuning), dan sel interstisial (panah hijau) yang normal. Pembesaran 10x10.

\section{Kelompok perlakuan I (P1)}

Tikus wistar kelompok P1 diberikan MSG sesuai dosis konsumsi rata-rata di Indonesia selama 20 hari, didapatkan sediaan testis yang memperlihatkan ruang tubulus semineferus yang kosong, hanya tampak spermatogonia pada membran basalis dan tidak terlihat perkembangan sel-sel spermatogenik sesuai tingkatannya (Gambar 2.1). Kelompok ini jelas memperlihatkan fokus-fokus tubulus semineferus yang mengalami atrofi. Namun tidak semua tubulus semineferus pada sediaan testis kelompok ini terlihat atrofi, masih ada tubulus semineferus yang berisi sel-sel spermatogenik sesuai tingkat perkembangannya walaupun kepadatan selselnya secara kualitatif berbeda dengan yang terlihat pada kontrol negatif (Gambar 2.2). Jumlah sel interstisial pada kelompok ini terlihat lebih sedikit dibandingkan dengan kontol negatif. 


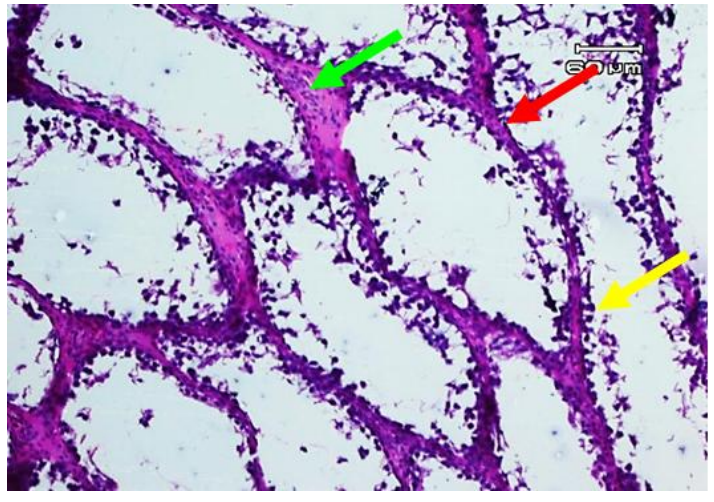

Gambar 2.1. Gambaran mikroskopik testis wistar kelompok perlakuan I/P1 (diberikan MSG selama 20 hari). Terlihat tubulus semineferus tanpa perkembangan sel-sel spermatogenik (panah merah) sehingga ruang tubulus tampak kosong, adanya lapisan spermatogonia yang saling jarang pada membran basalis (panah kuning), dan jumlah sel interstisial terlihat lebih sedikit daripada kontrol negatif (panah hijau). Pembesaran 10x10.

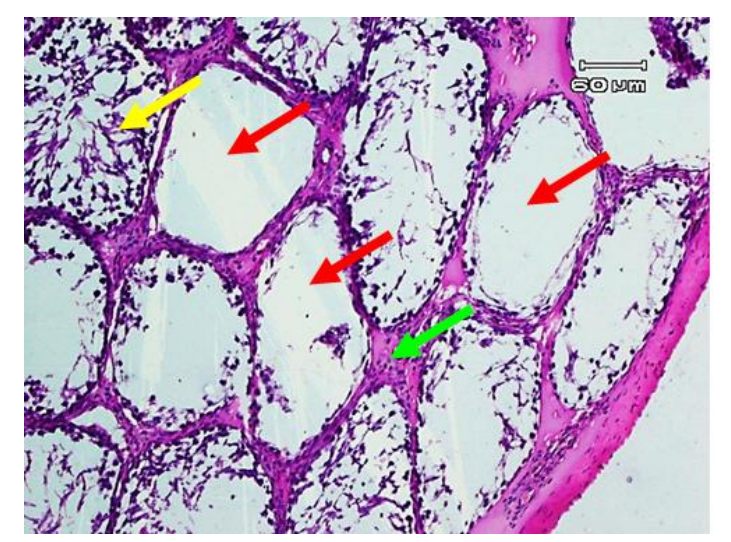

Gambar 2.2. Gambaran mikroskopik testis wistar kelompok perlakuan I/P1 (diberikan MSG selama 20 hari). Terlihat fokus-fokus tubulus semineferus yang mengalami atrofi (panah merah), tampak pula adanya tubulus semineferus yang masih berisi sel-sel spermatogenik namun kepadatannya tampak berbeda dengan kontrol negatif (panah kuning), dan jumlah sel interstisial lebih sedikit (panah hijau) dari kontrol negatif. Pembesaran $10 \times 10$.

\section{Kelompok kontrol negatif II (K2)}

Tikus wistar kelompok ini merupakan kelompok kontrol negatif untuk perlakuan 40 hari; didapatkan sediaan testis yang normal. Pada sediaan ini tampak tubulus semineferus dengan susunan lapisan sel spermatogenik yang normal. Sel spermatogenik tersusun berlapis sesuai dengan tingkat perkembangannya dari membran basalis menuju ke arah lumen tubulus yakni spermatogonia,spermatosit, spermatid hingga spermatozoon (Gambar 3).

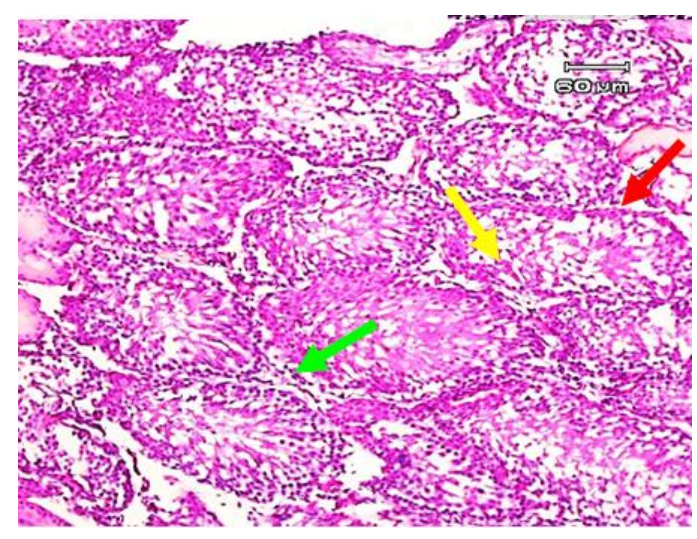

Gambar 3. Gambaran mikroskopik testis wistar Kelompok kontrol negatif 40 hari (K2). Terlihat tubulus semineferus (panah merah) dengan lapisan sel spermatogenik (panah kuning), dan sel interstisial (panah hijau) yang normal. Pembesaran 10x10.

\section{Kelompok perlakuan II (P2)}

Tikus wistar kelompok ini diberi MSG sesuai dosis konsumsi rata-rata di Indonesia selama 40 hari. Pada sediaan ini didapatkan adanya fokus-fokus tubulus yang kosong, tidak ada perkembangan sel-sel spermatogenik di dalamnya (Gambar 4.1). Sediaan jaringan testis kelompok ini tampak tak jauh berbeda dengan kelompok perlakuan II (P2), namun didapatkan 1 sediaan testis memperlihatkan tubulus semineferus tampak berisi sel-sel yang mengalami kalsifikasi (Gambar 4.2). Jumlah sel interstisial juga tampak lebih sedikit dari kontrol negatif. 


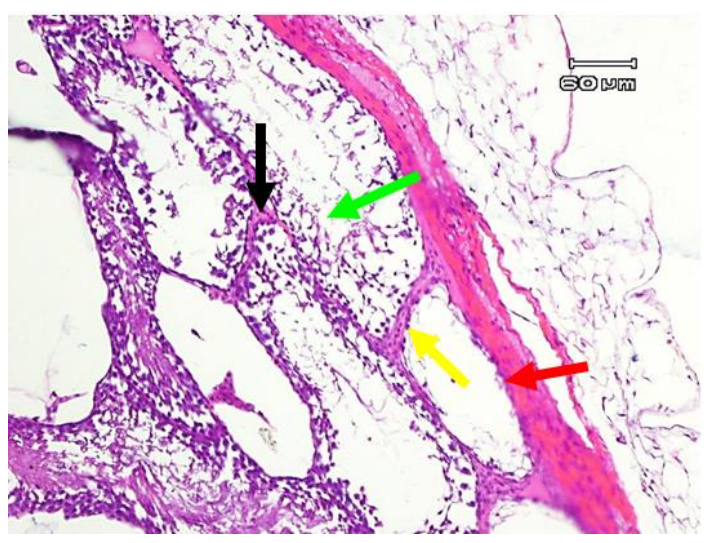

Gambar 4.1. Gambaran mikroskopik kelompok perlakuan MSG selama 40 hari (P2), memperlihatkan fokus tubulus semineferus yang tampak kosong (panah merah), terlihat hanya ada lapisan sel spermatogonium saja pada membran basalis (panah kuning). Adanya tubulus semineferus yang berisi sel-sel spermatogenik namun tampak longgar dan tidak teratur (panah hijau). jumlah sel interstisial terlihat lebih sedikit dari kontrol negatif (panah hitam). Pembesaran 10x10.

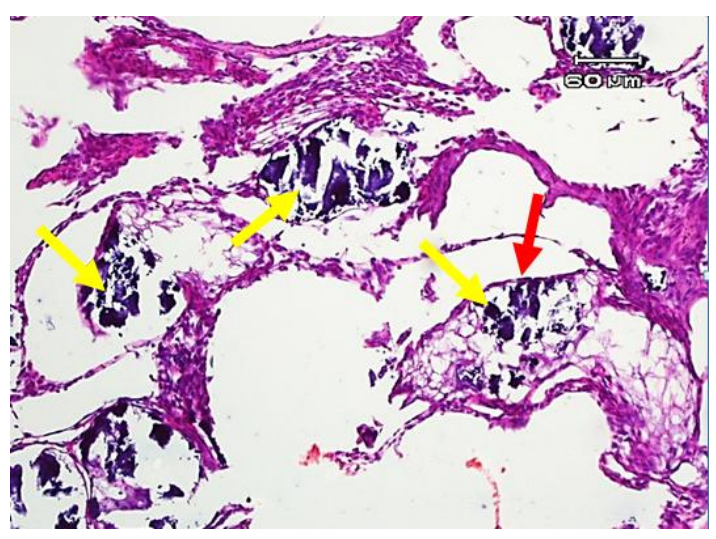

Gambar 4.2. Gambaran mikroskopik testis wistar kelompok perlakuan MSG selama 40 hari (P2), memperlihatkan adanya fokus-fokus tubulus semineferus (panah merah) yang berisi sel-sel spermatogenik yang mengalami kalsifikasi (panah kuning). Pembesaran 10x10.

\section{Diameter Tubulus Semineferus}

Pengukuran diameter tubulus semineferus didasarkan atas penelitian sebelumnya oleh Wongkar (2014) ${ }^{13}$. Pengukuran diameter tubulus semineferus dilakukan dengan cara mengukur jarak terpanjang dan jarak terpendek dari tubulus semineferus yang bentuknya bulat atau dianggap bulat menggunakan mistar $(\mathrm{mm})$ pada sediaan jaringan testis dengan pembesaran yang sama $(10 \times 10)$. Jumlah tubulus yang diukur adalah 4 tubulus dari tiap-tiap sediaan jaringan testis kemudian dihitung nilai rata-ratanya (Tabel 1). Hasil pengukuran dalam skala milimeter kemudian dikonversi ke dalam skala mikrometer dengan berpatokan pada jarak kalibrasi mikroskop yakni $60 \mu \mathrm{m}$ sama dengan $18 \mathrm{~mm}$ pada tampilan layar komputer. Jadi rumus untuk mencari diameter tubulus semineferus adalah $60 \mu \mathrm{m}$ dibagi $18 \mathrm{~mm}$, dikali ukuran jarak (mm).

Hasil pengukuran diameter tubulus semineferus menunjukkan bahwa kelompok wistar yang diberi perlakuan MSG dengan dosis konsumsi rata-rata di Indonesia selama 20 dan 40 hari memiliki diameter tubulus semineferus yang relatif lebih rendah dari semua kelompok kontrol negatif.

\section{Jumlah Lapisan Sel Spermatogenik}

Pengamatan jumlah lapisan sel spermatogenik didasarkan atas penelitian sebelumnya oleh Hargono (2013) ${ }^{14}$. Sel spermatogenik tersusun berlapis sesuai tingkat perkembangannya dari membran basalis menuju ke arah lumen tubulus yakni spermatogonia, spermatosit, spermatid sampai spermatozoon. Pengamatan jumlah lapisan sel spermatogenik pada tubulus semineferus secara melingkar pada 4 tubulus yang berdekatan dengan menghitung jumlah lapisan sel spermatogenik tidak terputus kemudian dihitung nilai rata-ratanya.

Hasil pengamatan menunjukan bahwa semua kelompok kontrol negatif memiliki sel-sel spermatogenik yang padat di dalam tubulus semineferusnya, rata-rata jumlah lapisan spermatogenik semua kelompok kontrol lebih banyak dibandingkan dengan kelompok wistar yang diberi perlakuan MSG selama 20 dan 40 hari (Tabel 2).

\section{Kepadatan Sel Interstisial}

Pengamatan kepadatan sel interstisial dilakukan secara kualitatif dengan cara melihat kumpulan sel interstisial yang berada 
diantara 3 sampai 4 tubulus semineferus dalam 4 lapang pandang dengan pembesaran 10x10 kemudian diinterpretasikan pada hasil gambaran mikroskopik masing-masing kelompok. Hasil pengamatan kepadatan sel interstisial menunjukkan bahwa pemberian MSG sesuai dosis konsumsi rata-rata di
Indonesia selama 20 dan 40 hari menyebabkan penurunan kepadatan sel interstisial. Kepadatan sel interstisial kelompok kontrol negatif terlihat jauh lebih padat dibandingkan dengan kepadatan sel interstisial kelompok yang diberi pelakuan (Gambar 1-Gambar 4.2).

Tabel 1. Hasil pengukuran diameter tubulus semineferus $(\mu \mathrm{m})$.

\begin{tabular}{|c|c|c|c|c|c|c|c|c|}
\hline & \multicolumn{2}{|c|}{ K1 } & \multicolumn{2}{|c|}{ P1 } & \multicolumn{2}{|c|}{ K2 } & \multicolumn{2}{|c|}{ P2 } \\
\hline & $\begin{array}{c}\text { DIAMETER } \\
\text { TERJAUH }\end{array}$ & $\begin{array}{l}\text { DIAMETER } \\
\text { TERDEKAT }\end{array}$ & $\begin{array}{c}\text { DIAMETER } \\
\text { TERJAUH }\end{array}$ & $\begin{array}{l}\text { DIAMETER } \\
\text { TERDEKAT }\end{array}$ & $\begin{array}{c}\text { DIAMETER } \\
\text { TERJAUH }\end{array}$ & $\begin{array}{l}\text { DIAMETER } \\
\text { TERDEKAT }\end{array}$ & $\begin{array}{c}\text { DIAMETER } \\
\text { TERJAUH }\end{array}$ & $\begin{array}{l}\text { DIAMETER } \\
\text { TERDEKAT }\end{array}$ \\
\hline A-T1 & 184.8 & 145.2 & 132 & 132 & 198 & 181.5 & 165 & 82.5 \\
\hline $\mathbf{T} 2$ & 283.8 & 115 & 247.5 & 99 & 224.4 & 178.2 & 161.7 & 95.7 \\
\hline T3 & 247.5 & 115 & 148.5 & 99 & 214.5 & 198 & 132 & 95.7 \\
\hline T4 & 214.5 & 198 & 198 & 99 & 214.5 & 132 & 135.3 & 82.5 \\
\hline B-T1 & 237.6 & 118.8 & 115.5 & 148.5 & 165 & 221.1 & 148.5 & 82.5 \\
\hline $\mathbf{T} 2$ & 158.4 & 115 & 151.8 & 99 & 227.7 & 145.2 & 148.5 & 92.4 \\
\hline T3 & 224.4 & 155.5 & 132 & 148.5 & 198 & 148.5 & 112.2 & 99 \\
\hline T4 & 214.5 & 125.4 & 165 & 115.5 & 204.6 & 165 & 181.5 & 99 \\
\hline C-T1 & 250 & 132 & 115.5 & 99 & 198 & 148.5 & 115.5 & 99 \\
\hline $\mathbf{T} 2$ & 181.5 & 165 & 115.5 & 99 & 181.5 & 115.5 & 148.5 & 115.5 \\
\hline T3 & 247.5 & 138.6 & 132 & 82.5 & 188.1 & 132 & 141.9 & 115.5 \\
\hline T4 & 148.5 & 135.3 & 99 & 181.5 & 181.5 & 165 & 165 & 99 \\
\hline D-T1 & 273.9 & 168.5 & 132 & 148.5 & 264 & 132 & 115.5 & 99 \\
\hline $\mathbf{T} 2$ & 188 & 165 & 231 & 115.5 & 234.3 & 207.9 & 165 & 66 \\
\hline T3 & 247.5 & 171.6 & 181.5 & $99 \mathbf{P 1}$ & $\mathbf{K}_{240.9}$ & $\overline{\mathbf{P 2}} 145.2$ & 99 & 89.1 \\
\hline T4 & 247.5 & 181.5 & 181.5 & 991 & $4_{198}$ & 155.1 & 132 & 132 \\
\hline E-T1 & 224.4 & 165 & 132 & 99 & 247.5 & 132 & 99 & 66 \\
\hline $\mathbf{T} 2$ & 247.5 & 99 & 148.5 & 115.5 & 214.5 & 115.5 & 112.2 & 72.6 \\
\hline T3 & 198 & 112.2 & 138.6 & 102.3 & 198 & 115.5 & 122.1 & 82.5 \\
\hline T4 & 217.8 & 155.1 & 181.5 & 99 & 247.5 & 148.5 & 99 & 105.6 \\
\hline $\begin{array}{l}\text { RATA- } \\
\text { RATA }\end{array}$ & \multicolumn{2}{|c|}{182.8} & & 33.9 & \multicolumn{2}{|c|}{183} & \multicolumn{2}{|c|}{114.2} \\
\hline
\end{tabular}

Tabel 2. Hasil pengamatan jumlah lapisan interstisial setiap kelompok percobaan 
Jurnal e-Biomedik (eBm), Volume 4, Nomor 2, Juli-Desember 2016

\begin{tabular}{ccccc}
\hline A-T1 & & & & \\
T2 & 4 & 1 & 4 & 1 \\
T3 & 4 & 1 & 4 & 2 \\
T4 & 3 & 3 & 4 & 2 \\
B-T1 & 4 & 1 & 4 & 1 \\
T2 & 4 & 1 & 4 & 1 \\
T3 & 4 & 1 & 4 & 1 \\
T4 & 4 & 1 & 4 & 1 \\
C-T1 & 4 & 2 & 4 & 1 \\
T2 & 4 & 2 & 4 & 3 \\
T3 & 4 & 1 & 4 & 1 \\
T4 & 4 & 1 & 4 & 1 \\
D-T1 & 3 & 1 & 4 & 1 \\
T2 & 3 & 2 & 4 & 3
\end{tabular}

Ket. : $\mathbf{T}=$ Tubulus, $\mathbf{T} \underline{\mathbf{3}}$ mineferus, $\mathbf{A}_{\overline{4}}=$ Tikus $\mathrm{A}_{2} \mathbf{B}=$ Tikus $\mathrm{B}, \mathbf{C}=$ Tikus $\mathbf{C}, \mathbf{D}=$ Tikus D

\begin{tabular}{ccccc} 
T4 & 4 & 2 & 4 & 2 \\
E-T1 & 4 & 2 & 3 & 1 \\
T2 & 4 & 2 & 4 & 3 \\
T3 & 4 & 2 & 4 & 3 \\
T4 & 4 & 1 & 4 & 1 \\
\hline $\begin{array}{c}\text { RATA- } \\
\text { RATA }\end{array}$ & 3.85 & 1.5 & 3.95 & 1.55 \\
\hline
\end{tabular}




\section{BAHASAN}

Pemberian MSG pada kelompok perlakuan sesuai dosis konsumsi rata-rata di Indonesia selama 20 dan 40 hari diperoleh gambaran mikroskopik sediaan testis tikus wistar yang berbeda dengan semua kelompok kontrol negatif, yakni didapatkan diameter tubulus semineferus yang lebih kecil, jumlah lapisan sel-sel spermatogenik yang lebih sedikit dan kepadatan sel interstisial yang berkurang secara kualitatif. Mekanisme yang berperan dalam hal di atas karena adanya efek neurotoksin yang ditimbulkan MSG pada sistem Hipotalamus-HipofisisGonad. ${ }^{15,16}$ Kemampuan MSG menimbulkan kerusakan pada Nukleus Arkuata di hipotalamus yang menyebabkan terjadinya penurunan hormon reproduksi. Nukleus arkuata memiliki neuron yang mensekresikan Gonadotropin Releasing Hormone (GnRH), karena terjadi lesi pada daerah ini maka terjadi gangguan sekresi GnRH. Terganggunya sekresi GnRH menyebabkan penurunan sekresi Luteinizing Hormone (LH) dan Follicle-Stimulating Hormone (FSH), kedua hormon ini sangat penting dalam menjalankan fungsi normal testis dan proses spermatogenesis.

Gambaran mikroskopik hasil penelitian di atas sejalan dengan Pakarainen (2006) ${ }^{17}$ dan Wang $(2009)^{18}$ dimana proses spermatogenesis pada mamalia sangat bergantung pada testosteron, oleh karena itu inhibisi hormon testosteron akibat tidak adanya stimulus dari Luteinizing Hormone (LH) pada kelompok yang diberi perlakuan MSG selama 20 hari (P1) dan 40 hari (P2) terjadi hambatan dalam proses spermatogenesis. Hal ini menyebabkan hambatan perkembangan sel-sel spermatogenik, hingga pada gambaran mikroskopik kelompok P1 memperlihatkan tubulus semineferus dengan susunan sel-sel spermatogenik yang berkurang dan tidak sesuai tingkat perkembangannya (Gambar 2.1, Gambar 2.2). Pada kelompok P2 memperlihatkan sediaan testis dengan fokusfokus tubulus semineferus yang tak jauh berbeda dengan kelompok P1, namun pada kelompok ini didapatkan satu sediaan testis yang memperlihatkan tubulus semineferus berisi sel-sel spermatogenik yang mengalami kalsifikasi (Gambar 4.1,Gambar 4.2). Hambatan pada perkembangan sel-sel spermatogenik memperlihatkan tubulus semineferus yang mengalami atrofi, terlihat pada kelompok P1 dengan fokus-fokus tubulus semineferus yang memberi gambaran lapisan sel-sel spermatogenik yang lebih sedikit dari kelompok kontrol negatif (Gambar 2.1, Gambar 2.2), begitupun pada tikus kelompok P2 memberi gambaran tubulus semineferus dengan lapisan sel-sel spermatogenik yang longgar dan tidak teratur (Gambar 4.1,Gambar 4.2). Adanya lapisan sel-sel spermatogenik ini memberi dampak pada ukuran diameter tubulus semineferus, kelompok P1 dan P2 memiliki rata-rata diameter tubulus semineferus yang lebih kecil diduga karena lapisan sel-sel spermatogeniknya lebih sedikit, bahkan terdapat tubulus yang hanya memiliki satu lapisan sel spermatogenik pada membran basalis. Dengan berkurangnya lapisan spermatogenik akibat penekanan pada proses spermatogenesis, menyebabkan dorongan spermatozoa dari dalam tubulus menjadi berkurang sehingga diameter tubulus semineferus juga berkurang. Hal ini sejalan dengan penelitian Sugeng $(2010)^{19}$ yang menyatakan bahwa gangguan perkembangan spermatozoa mengakibatkan penurunan pada diameter tubulus semineferus, dan menurut Anindita $(2008)^{20}$ yang menyatakan bahwa peningkatan proses spermatogenesis dapat meningkatkan diameter tubulus semineferus dan berat testis.

Jumlah sel interstisial yang lebih sedikit pada kelompok P1 dan kelompok P2 dibandingkan dengan kelompok kontrol negatif diduga terjadi akibat degenerasi selsel interstisial melalui mekanisme apoptosis atau kematian pada beberapa sel tanpa diikuti secara seimbang proses pembelahan atau penambahan sel anak lagi. Hal ini disebabkan tidak adanya rangsangan hormon gonadotropin terhadap sel interstisial, pada penelitian Suryadi $(2007)^{21}$ menyatakan 
bahwa terganggunya sistem pada axis hipotalamus-hipofisis-gonad akan menyebabkan terjadinya penurunan sekresi hormon gonadotropin, karenanya terjadi penurunan hormon LH dan FSH. Penurunan LH tepatnya menyebabkan stimulasi terhadap sel interstisial (Leydig) berkurang sehingga dapat menurunkan aktivitasnya dalam proses pembelahan maupun dalam mensintesis hormon testosteron. Akibatnya, jumlah sel interstisial menjadi lebih sedikit dan diameter intinya menjadi lebih kecil.

Menurut Alalwani (2014) $)^{3}$ dan Mohamed (2012) ${ }^{4}$ gambaran histopatologik testis tikus wistar yang diberi MSG tidak hanya disebabkan oleh mekanisme kerusakan yang disebabkan MSG melalui sistem hipotalamus-hipofisis-gonad saja, melainkan ada dua mekanisme lainnya. Mekanisme pertama, dipercaya bahwa testis merupakan organ target dari MSG karena terdapat reseptor dan transporter glutamat pada selsel epitel tubulus semineferus, namun bagaimana mekanisme kerusakan yang ditimbulkan masih belum didapatkan buktibukti penelitian ilmiahnya. ${ }^{22,23}$ Mekanisme kedua, MSG menyebabkan terbentuknya radikal bebas yang berlebih dan menimbukan stress oksidatif. Testis sebagai tempat berlangsungnya spermatogenesis bersifat sangat rentan terhadap proses oksidasi oleh radikal bebas. Radikal bebas ini akan menimbulkan gangguan pada spermatogenesis dan membran spermatozoa. Membran sel spermatogenik mengandung sejumlah besar asam lemak tak jenuh rantai ganda. Bila radikal bebas yang terbentuk bertemu dengan asam lemak tak jenuh ganda dalam membran sel, akan terjadi reaksi peroksidasi lipid dari membran sel tersebut yang mengakibatkan peningkatan fluiditas membran, gangguan integritas membran dan inaktifasi ikatan membran dengan enzim dan reseptor. Hal ini akan menyebabkan peningkatan kerusakan sel termasuk spermatozoa, penurunan jumlah spermatosit dan spermatid. ${ }^{24-7}$

Pada perlakuan selama 20 hari terlihat fokus-fokus tubulus semineferus yang mengalami atrofi, namun juga terlihat beberapa tubulus semineferus yang masih memiliki sel-sel spermatogenik didalamnya. Walaupun begitu hal ini tentu mampu menyebabkan disfungsi seksual atau infertilitas yang akan bermanifestasi secara klinis dengan oligozoospermia.

Penggunaan MSG di Indonesia per hari masih terhitung sangat rendah dibandingkan di negara industri maupun negara maju, meskipun begitu dosis konsumsi rata-rata di Indonesia ternyata dapat menimbulkan efek pada gambaran histologik testis wistar. Dalam penelitian ini terdapat banyak kekurangan antara lain dalam hal jumlah sampel, subjek penelitian, waktu penelitian yang singkat (40 hari) dan tidak meneliti efek MSG pada berbagai organ tubuh lain selain testis.

\section{SIMPULAN}

Berdasarkan penelitian ini disimpulkan bahwa pemberian MSG sesuai dosis konsumsi rata-rata di Indonesia selama 20 dan 40 hari menunjukkan gambaran histopatologik testis tikus wistar (Rattus norvegicus) yang hampir sama yaitu diameter tubulus semineferus yang mengecil, jumlah lapisan sel-sel spermatogenik yang berkurang dan kepadatan sel interstisial menurun.

\section{SARAN}

1. Perlunya dilakukan penelitian lebih lanjut dengan menggunakan subjek penelitian hewan coba lain.

2. Perlunya penambahan jumlah sample untuk penelitian agar dapat dilakukan uji statistik.

3. Dibutuhkan waktu penelitian yang lebih lama untuk melihat lebih jauh efek pemberian MSG terhadap gambaran histologik testis.

4. Perlunya pemeriksaan kadar hormon testosteron sebagai pemeriksaan akurat terhadap fungsi dari sel-sel interstisial.

\section{DAFTAR PUSTAKA}

1. Septadina IS. Pengaruh monosodium glutamat terhadap 
sistem reproduksi [makalah fungsional]. diseminarkan di Bagian Anatomi; 16 Januari 2014; Fakultas Kedokteran Universitas Sriwijaya.

2. Walker R, Lupien J. The safety evaluation of monosodium glutamate. J Nutr. 2000;130:1049S-52S.

3. Alalwani AD. Monosodium glutamate induced testicular lesions in rats (histological study). Middle East Fertility Society Journal. 2014;19(4):27480.

4. Mohamed IK. The effect of oral dosage of monosodium glutamate applied for short and long term on the histology and ultrastructure of testes of the adult rats. Journal of Animal and Veterinary Advanced. 2012;11(1):124-133.

5. International Glutamate Information Service. What is MSG?. 2016 [cited 2016 oct 30]. Available from: http://www.glutamate.org/Englis $\mathrm{h} /$ faqs/faqs.html.

6. Departement of Food Science and Toxicology. IFIC review of monosodium glutamate, examining the myths. May 1994 [cited 2016 sep 5]. Available from:

http://extoxnet.orst.edu/faqs/addit ive/ificmsg.html.

7. Sukmaningsih AASA, Ermayanti IGAM, Wiratmini NI, Sudatri NW. Gangguan spermatogenesis setelah pemberian monosodium glutamat pada mencit. Jurnal Biologi. 2011;15(2):49-52.

8. Food and Drug Administration Backgrounder. FDA and monosodium glutamate (MSG). 1995 Aug 31 [cited 2016 sept 5]. Available from: http://www.emagill.com/rants/fd a_msg.pdf.
9. Madaniyah S, Lioe HN, Andarwulan N, Briawan D, Nuraida L. Free glutamate intake from foods among adults: case study in bogor and jakarta. Jurnal Mutu Pangan. 2014;1(2):100-109.

10. Ardyanto TD. MSG dan kesehatan: sejarah, efek dan kontroversinya. INOVASI. 2004;1(XVI):52-6.

11. Geha R, Beiser A, Ren $C$, Patterson R, Grammer L, Ditto A, et al. Review of allergic reaction to monosodium glutamate and outcome of a multicenter double blind placebo-controlled study. J Nutr. 2001;130:1032S-8S.

12. Prawirohardjono W, Iwan D, Indwiani A, Soeliadi H, Erna $\mathbf{K}$, Mustofa M, et al. The administration to Indonesians of monosodium l-glutamate in Indonesian foods : an assessment of adverse reactions in a randomized double blind, crossover, placebo-controlled study. J Nutr. 2000;130:1074-6.

13. Wongkar J. Efek pemberian anabolik steroid injeksi dosis rendah dan tinggi terhadap gambaran morfologi testis wistar [skripsi]. Fakultas Kedokteran Universitas Sam Ratulangi: 2014.

14. Hargono FR. Gambaran histopatologik testis mencit yang diberi kedelai dan paparan dengan asap rokok [skripsi]. Fakultas Kedokteran Universitas Sam Ratulangi: 2013.

15. Gong SL, Xia FQ, Wei J, Li XY, Sun TH, Lu Z, et al. Harmful effects of MSG on function of hypothalamus-pituitary-target gland system. Biomed Environ Sci. 1995;8:310-7. 
16. Giovambattista A, Suescun M, Nessralla C, Franca L, Spinedi E, Calandra R. Modulatory effects of leptin on leydig cell function of normal and hyperleptinemic rats. Neuroendocrinology. 2003;78:270-9.

17. Pakarainen T, Zhang F, Makela S, Poutanen M, Huhtaniemi I. Testosterone replacement therapy induces spermatogenesis and partially restores fertility in luteinizing hormone receptor knockout mice. Endocrinology. 2005;146:596-606.

18. Wang R, Yeh S, Tzeng C, Chang C. Androgen receptor roles in spermatogenesis and fertility: lessons from testicular cellspecific androgen receptor knockout mice. Endocrinol Rev. 2009;30:119-32.

19. Sugeng SI, Tiono H, Anandaputri VN. Pengaruh pasta tomat (solanum lycopersicum) terhadap diameter tubulus semineferus mencit (Mus musculus) galur DDYyang terpajan asap rokok berfilter. Jurnal Kedokteran Maranatha. 2010;10:47-54.

20. Anindita K, Sutyarso. Pengaruh pemberian vitamin $\mathrm{C}$ terhadap berat testis, jumlah sel leydig, dan diameter tubulus semineferus mencit (Mus musculus) jantan dewasa yang diinduksi monosodium glutamate [skripsi]. Universitas Lampung: 2008.

21. Suryadi E, Iryani D, Suryono SK. Perubahan sel-sel Leydig tikus putih jantan dewasa setelah pemberian monosodium glutamat oral. Jurnal Anatomi Indonesia. 2007;1:120-32.

22. Gill S, Mueller $\mathbf{R}$, Mcguire $\mathbf{P}$, Pulido O. Potential target sites in peripheral tissues for excitatory neurotransmission and excitotoxicity. Toxicol Pathol. 2000;28:277-84.

23. Takarada T, Hinoi E, Balcar V, Taniura H, Yoneda Y. Possible expression of functional glutamate transporters in the rat testis. J Endocrinol. 2004;181:233-44.

24. Nayanatara A, Vinodini N, Damadar G, Ahemed B, Ramaswamy C, Shabarinath M, Bhat M. Role of ascorbic acid in monosodium glutamate mediated effect on testicular weight sperm morphology and sperm count in rat testis. J Chin Clin Med. 2008;3:1-5.

25. Vinodini NA, Nayanatara A, Damodar G, Damodar B, Ramaswamy CR, Shabarinath, Bhat MR. Effect of monosodium induced oxidative damage on rat testis. J Clin Med. 2010;3:370-3.

26. Moreno G, Perello M, Gaillardand RC, Spine E. Orexin a stimulates hypothalamicpituitary-adrenal (HPA) axis function, but not food intake in the absence of full hypothalamic NPYergic activity. Endocrine. 2005;26:99-106. Farmobi E, Onyema O. Monosodium glutamate-induced oxidative damage and genotoxicity in the rat modulatory role of vitamin $\mathrm{C}$, vitamin $\mathrm{E}$ and quercetin. Hum Exp Toxicol. 2006;25:251-9.

27. Pavlovic V, Kocic D, Sokolovic D. Effect of monosodium glutamate on oxidative stress and apoptosis in rat thymus. $\mathrm{J}$ Mol Cell Biochem. 2007;303:161-6. 